\title{
A Study on Community Involvement in the Development of Secondary Schools
}

\author{
* Dr. Munir Khan, Assistant Professor \\ ** Dr. Iqbal Amin Khan, Lecturer \\ *** Dr. Muhammad Nisar, Principal
}

\begin{abstract}
This study aimed to examine community involvement in secondary level school development Malakand District. The aims of the researcher were to explore the involvement of the community, participation, adjustments and interest in school development activities. The population of this study was all the heads and teachers of the Malakand District Government Secondary schools. Through random sampling, the researcher selected 20 principalals and 60 teachers both male and female. The quantitative method of study was introduced and data collected through a questionnaire consisting of twenty-three questions. It was found in this study that the community members were involved in the development of the school. The members of the community attend school meeting with staff and check the achievement and progress of their children at school. The schools encouraged community participation and were sharing their students' progress report with parents. The community members raised no funds for schools, so the researcher suggests that community members support these efforts to encourage school growth, and community members should have a clear time to address the issue with staff.
\end{abstract}

Keywords: Community Model, Community Members, Child Achievements Introduction

Human and cultural development is subject to the individuals' level of achievement in instructional exercise. Accordingly, teaching as an instrument for countrywide development and reform has been uniformly standard. Preparing on the loose has natural and alien qualities for both the individual and the general public.

Community gives a domain where we build up the aptitudes and procure the information that can assist us with having any kind of effect in our quickly evolving society. It endeavors to give us chances to settle on choices and support to fulfil our scholarly needs capably and adequately. Community characterized as; "a number of persons alive together in the equivalent region and underneath the equivalent public". It involves gatekeepers, guardians, tenants, associations and associations, etc. The framework may be found in articulations of the sum of the people or establishment of individuals staying inside a picked geographical district nearby a village, a city, a region, and conceivably the entire country.

The system, while therefore abstract, is used in two identifies; the first one as a social unit, and the other as a unit of land. This deduces that such individual associations are energetically joined and subordinate (Watson, 1998). Many persons resisting inside the vague portrayed spot sharing the vague fundamental characteristics, association and interests (Rafkin, 1988).

The term "affiliation" is decrypted in different manners, clarifies levels or levels of commitment at world class level, and offers seven potential definitions and articulations, including consideration by means of methodologies for the essential use of a conveyor, which focus on the drawing in the nature of conclusions made by methods for other people; Participation by spending cash, resources and troubleshooting work; consideration of the character of the problems, likelihood, control and evaluation by the approach of the father and mother to workforce, and partnership "in each stage of a professional decision-making process" (Shaeffer, 1994).

Groups' participation does not typically require the accommodating involvement of program individuals, but it is about how members carry on to the point of their ordinary life. The best way to consider and confirm the system is to improve it is subject to information shared with participants. In order to make a real use of the aid of society in systems that are participating in certified insurance at

* Department of Education, University of Malakand, Dir Lower Email: drmunirkhan71@ gmail.com

** Department of Education, University of Malakand, Dir Lower Email: iqbalphd.scholar@yahoo.com

*** Department of Education, SUIT, Peshawar. Email: nisarkust74@ gmail.com 
every degree, the ladder leads from an understated progress where "there is the ability of organizations to proactively begin improvements and the certitude that their own one kind of ladder steps of a Schaeffer are taking place (Shaeffer 1994).

Community investment is a premium for the planning and enhancement of neighbourhood condition and is one of the main elements of employee sufficiency through methods of encouraging mother and dad to catch up on favourable circumstances in their teens coaching. It can be used as an incentive to return to the school and its abstract improvement. The school offers five classes of observational and framing aid that are local material: teenagers attend an optional school that is selected to teach; the framework supports the staff in tax and texture; the verbal exchange between school, mother and father and the system is visited; In school organizations the framework has an important circumstance; and framework individuals and vigils help prepare (Heneveld and Craig, 1996).

Community cooperation is an essential view to keeping a close eye on the disaster of school frustration and notes that solid schools make up memberships to promote higher learning objectives and extra animated students. The fundamental and teacher preferences demonstrated that the teachers working hard and advancing their school have gained ability within the workplace and specialists were typically encouraged more and verbal exchanges between the staff and the school system have advanced. At each stage, the confirmation certifies the pupils, with little regard for plans, the advantages or the history of relatives and the evaluation shows choices. The minority's educational achievement through all races has an impact on consideration (Gorgendiere, 1997).

Community and even parents involved in the private and school activities of their children provide an essential means of improving social and academic results for specific and understudies (Hill, Tyson, 2009). The tutoring system 's duty goes lower early in the 20th century while spots of affection and undeniable non-standard affiliations and other lasting efforts in this area (Bray, 2003). The promotion of economic improvement that controls the way to social consideration is supported by education. It is one of the fundamental conditions for personal satisfaction. In the end, a widespread approach to quality information and skills ensures that all have an equal opportunity to have a full impact on employment and society (Inonda, M.; Riechi, S, 2009). In this sense, it is fundamental to incorporate in the public arena the minimum and defenceless into the procedure for improvement that promotes the value and dynamic citizenry through an all-round training and the preparation frame.

However, when, in any case, the advantages of education are obvious, the necessary direness in the advancement plan for many few countries does not appear at present to be guaranteed (Ohba, 2012). Similar to the auxiliary schools in creating countries and particularly in this regard, there is nothing but significant concern in Puntland, where the network is part of the teaching cycle. A major supporter of youth achievement in schools, as (BaizM., 2013), notes that the involvement of the family is an enormous influence on school success. (DeGrauwe, 2006) Specified the creation of a joint initiative between educators and guardians in much of the Organization for economic co-activity and development (OECD) nations. This connection contributes to the development of learning in high school administration and thus enhances young people. An analysis by (Ballen, C., McClelland et al., 2013), of school network links in the past 15 years has found that a few parent and network association programs generously strengthened under-study and its achievement in basic and secondary schools. However (Campbell, 2012). It is not clear who is responsible in the presentation of discretionary schools in most schools of the countries of production for parent and program commitment. The affiliation of school-social orders involves the school and the system to share the obligation to run schools and to help young people achieve their preparatory goals, without the benefit of either the school or the system (Tondeur, 2013).

The justification for the network's participation in its organisation and making of choices depends upon the assumption that its citizens do have the benefit of participating because they have the responsibility to decide network requirements, choose needs and choose the most suitable network asset component methodology. As individuals can be interested in making choices, goals of the figurative program become their own aspirations and, in this way, they are extremely willing to update them effectively. (Decker \& Decker 1991). 1991. The government understood that except if forces and dynamic procedures in the organization and association of guidance and planning, which 
were seriously collected at the peaceful level were decentralized, the country couldn't improve its enlightening undertakings (Omea,2017)

Bray (2000) states. Inclusion in management roles (ordering, sorting, scheduling and correspondence) in auxiliary instructive improving is now more important than ever in the Community's management role. This is because the Primary school Education Development Program (PEDP) and its resulting increase at a constant rate of 40 percent in 2003 are rapidly increasing grade school enrolment rates.

It is agreed that during the period of decentralization the participation of the Group will significantly enhance the competence, efficiency, transparency and response of administrative structures as opposed to consolidated frameworks. Decentralized education is also said to be gradually effective, reflecting neighbourhood needs better, enabling support and inevitably, improving inclusion and quality (Faustor, 1995).

\section{Statement of the Problem}

The study key objective was to assess the community involvement in development of school at secondary Level in District Malakand.

\section{Objectives of the Study}

Objectives of the study were:

1. To find out the role of educational growth in school with respect to community participation.

2. To discuss the different aspects of school's physical development related to community involvement.

\section{Significance of the Study}

This study would be useful to policy makers, educational administrators, school heads, teachers and their parents for the sake of community growth and in the Malakand 's advancement of school activities. This research plays a critical role in enhancing the quality of school community physical structure through community involvement.

\section{Delimitation of the Study}

Due to insufficient time and only government secondary school of District Malakand were selected as data

\section{Methods and Procedure}

Data is consistently accumulated through surveys of other genuine mechanical assemblies in this system. It is a smart and basic system in which data can be accumulated to the point while also saving the time of the researchers that the explanation investigator has obtained this methodology for his assessment. The survey-based research methodology and the nature of the description.

\section{Population}

All Government secondary schools of Malakand District have been chosen as a population of the study.

\section{Sample}

The study sample was shown in table below:

\begin{tabular}{lccc}
\hline \multicolumn{3}{c}{ Malakand District } \\
\hline Heads & Male & Female & Total \\
Teachers & 10 & 10 & 20 \\
Total & 30 & 30 & 60 \\
\hline
\end{tabular}

\section{Research Instruments}

Researcher was used Questionnaires as a research tool. Two questionnaires were prepared.

1. One questionnaire for Principals

2. One for teachers of secondary schools

\section{Data Collection}

The field data was collected through questionnaires. The data obtained from the target sampling at secondary schools' level in the District Malakand.

\section{Data Analysis}

For data analysis statistical techniques such as Chi square were used. Conclusions were drawn on the basis of data analysis, and suggestions were made. 


\section{Results and Discussion}

The results for each problem appear as clearness values, but the chi-square counts are rendered using the recurrent knowledge. Gathering of information is done where any classification dips under 5\% or five respondents and the degrees of opportunity are diminished as needs be. The examples are as per the following: Heads: $\mathrm{N}=20$; Teachers: $\mathrm{N}=60$; and $\mathrm{N}=80$. The low example in the initial two gatherings diminishes the affectability of chi-square significantly.

Table 4.1 For School Development

\begin{tabular}{|c|c|c|c|c|c|c|c|c|c|c|}
\hline & & A & SA & $\overline{\text { DA }}$ & UD & $\overline{\text { SDA }}$ & Total & $\mathbf{X}^{2}$ & df & Sig \\
\hline Principal & $\mathrm{F}_{\mathrm{o}}$ & 3 & 17 & $\mathbf{0}$ & $\mathbf{0}$ & $\mathbf{0}$ & 20 & .305 & 2 & .859 \\
\hline Male Teacher & $\mathrm{F}_{\mathrm{o}}$ & $\begin{array}{l}15.0 \% \\
\mathbf{4} \\
13.3 \%\end{array}$ & $\begin{array}{l}85.0 \% \\
\mathbf{2 6} \\
86.7 \%\end{array}$ & & & & $\begin{array}{l}100 \% \\
\mathbf{3 0} \\
100 \%\end{array}$ & & & \\
\hline Female Teacher & $\mathrm{F}_{\mathrm{o}}$ & $\begin{array}{l}\mathbf{3} \\
10.0 \%\end{array}$ & $\begin{array}{l}27 \\
90.0 \%\end{array}$ & & & & $\begin{array}{l}30 \\
100 \%\end{array}$ & & & \\
\hline Total & & $\begin{array}{l}\mathbf{1 0} \\
12.5 \%\end{array}$ & $\begin{array}{l}\mathbf{7 0} \\
87.5 \%\end{array}$ & & & & $\begin{array}{l}80 \\
100.0 \%\end{array}$ & & & \\
\hline
\end{tabular}

*Significant

The table depicts that the statement was agreed by 100 per cent of school heads. Though females were equally more favourites than male teachers.

Table 4.2 Competent in their respective work

\begin{tabular}{lclllllllll}
\hline \multicolumn{2}{c}{ SDA } & & DA & UD & A & SA & Total & $\mathbf{X}^{2}$ & df & Sig \\
\hline Principal & $\mathrm{F}_{\mathrm{o}}$ & $\mathbf{1}$ & $\mathbf{1}$ & $\mathbf{2}$ & $\mathbf{1 1}$ & $\mathbf{5}$ & $\mathbf{2 0}$ & $7.043^{\mathrm{a}}$ & 8 & .532 \\
Male Teacher & & $5.0 \%$ & $5.0 \%$ & $10 \%$ & $55 . \%$ & $25 \%$ & $100 \%$ & & & \\
& $\mathrm{~F}_{\mathrm{o}}$ & $\mathbf{2 3}$ & $\mathbf{1 2}$ & $\mathbf{1 3}$ & $\mathbf{3 0}$ & & $\mathbf{3 0}$ & & & \\
Female Teacher & & $0 \%$ & $16.7 \%$ & $10 \%$ & $40 \%$ & 43.3 & $100 \%$ & & & \\
& $\mathrm{~F}_{\mathrm{o}}$ & $\mathbf{0}$ & $\mathbf{0}$ & $\mathbf{2}$ & $\mathbf{1 6}$ & $\mathbf{1 2}$ & $\mathbf{3 0}$ & & & \\
Total & & $0 \%$ & $0 \%$ & $6.7 \%$ & $53.3 \%$ & $40 \%$ & $100 \%$ & & & \\
& & $\mathbf{1}$ & $\mathbf{3}$ & $\mathbf{7}$ & $\mathbf{3 9}$ & $\mathbf{3 0}$ & $\mathbf{8 0}$ & & & \\
& $1.2 \%$ & $3.8 \%$ & 8.8 & $48.8 \%$ & 37.5 & $100.0 \%$ & & &
\end{tabular}

*Significant

The table shows that 80 per cent of heads were in agreement with the above articulation. While relatively female teachers are accepted more within than male teachers.

Table 4.3 Involved in the school development plans

\begin{tabular}{|c|c|c|c|c|c|c|c|c|c|c|}
\hline \multirow{3}{*}{ Principal } & & SDA & DA & UD & A & SA & Total & $\mathbf{X}^{2}$ & df & Sig \\
\hline & $\mathrm{F}_{\mathrm{o}}$ & 1 & 1 & 2 & 10 & 6 & 20 & $3.602^{\mathrm{a}}$ & 8 & .891 \\
\hline & & $5.0 \%$ & $5.0 \%$ & $10 \%$ & $50 \%$ & $30 \%$ & $100 \%$ & & & \\
\hline Male Teacher & $\mathrm{F}_{\mathrm{o}}$ & $\begin{array}{l}\mathbf{2 3} \\
6.7 \%\end{array}$ & $\begin{array}{l}\mathbf{1 2} \\
10 \%\end{array}$ & $\begin{array}{l}\mathbf{1 3} \\
10 \%\end{array}$ & $\begin{array}{l}\mathbf{3 0} \\
40 \%\end{array}$ & $33.3 \%$ & $\begin{array}{l}\mathbf{3 0} \\
100 \%\end{array}$ & & & \\
\hline Female Teacher & $F_{o}$ & $\begin{array}{l}\mathbf{1} \\
3.3 \%\end{array}$ & $\begin{array}{l}2 \\
6.7 \%\end{array}$ & $\begin{array}{l}7 \\
23.3 \%\end{array}$ & $\begin{array}{l}11 \\
36.7 \%\end{array}$ & $\begin{array}{l}9 \\
30 \%\end{array}$ & $\begin{array}{l}30 \\
100 \%\end{array}$ & & & \\
\hline Total & & $\begin{array}{l}4 \\
5 \% \\
\end{array}$ & $\begin{array}{l}\mathbf{6} \\
7.5 \%\end{array}$ & $\begin{array}{l}\mathbf{1 2} \\
15 \%\end{array}$ & $\begin{array}{l}33 \\
41.2 \% \\
\end{array}$ & $\begin{array}{l}\mathbf{2 5} \\
31.2 \% \\
\end{array}$ & $\begin{array}{l}80 \\
100.0 \% \\
\end{array}$ & & & \\
\hline
\end{tabular}

*Significant

The above table shows that $80 \%$ of principals agreed with development plans. While male teachers are similarly more agreed inside than female teachers are.

\section{Findings}

The investigation 's significant destinations existed to distinguish community involvement in Malakand District. After investigation of information the study discoveries such as:

1. The role of the Community association was fundamental for the advancement of schools.

2. It has been found that in Community involvement the sperate work for the individual.

3. It was discovered that individuals in the community were engaged in arranging procedures for school development. 
4. It was determined that individuals from the Community were consistently refreshing for execution of the school.

5. To the community the school atmosphere and their participation in physical school development is appropriate.

6. The individuals did not arrange resources for collecting pledges to enhance the school as per group engagement guideline.

7. Public engagement was strengthened by oversight of the public facilities and academic matters.

\section{Conclusion}

1. It was found that the role of the school community in terms of participation and affiliation was for the improvement of the school as they were talented in their individual work; they recognized execution of the school and looked at making action courses for the school headway.

2. It was founded that the schools have community people who are closely watching the issues related to their school and solving the issues for helping with school building, gave satisfactory data on how to make approaches for different events, and stimulated the understudies to exhibit incredible academic success.

\section{Recommendations}

In view of the above outcomes of this study, going with this proposal are made for extra school improvement.

1. The study result shows that government and people did not inform society about school change, and it is proposed that they will highlight capital by moving the system's affluent individuals.

2. Community participation should go to school and visit the community school and discuss insightful issues with the principal and the female system people can also visit schools to look at undergraduate studies.

\section{Reference}

Ajmera, R. (2014). Parent and community involvement in schools.

Baiz, M. (2013). Parent Involvement in Education: Possibilities and limitations. the school community Journal 6(1), , Spring/Summer.

Ballen,C., ; Moles, T. (2013). Critical Issue: Contructing school partnerships with families and community groups. Community Practitioners Journal, 82(2) ,, pp. 28-31.

Bray, M. (2000). Community Partnerships in Education: Dimensions, Variation and Implications. Paris: Education for All (EFA) Inter- Agency Commission, UNESCO.

Bray, M. (2003). Community initiatives in education: goals, dimensions and lingkages with governments. Compare, 31-45.

Campbell, C. (2012). How to Involve Hard-to-Reach Parents: Encouraging Meaningful Parent Involvement with Schools. Manchester: Research Associate.

DeGrauwe, T. (2006). Community and Parenting Programme: Barriers and Best Practice. Community Practitioner Journal, Vol. 82(2) , 28-31.

Decker, L.E. and Decker, V.A (1999). Home/School/Community Involvement. Virginia - American Association of School Administrators.

Faustor, C.N. (1995). Decentralization and Planning of Education: Experiences in Five Latin American Countries, Retrieved, January, 16, 2007, from www.voced.edu.au/td/tnc-68.479$17 \mathrm{k}$.

Gorgendiere, D. 1. (1997). community involvement in school development , 19.

Inonda, M. ; Riechi, S. (2009). Radical Reforms in Kenya's Education Section Sector: Implementing Policies Responsive to Vision 2030. Nairobi: IPAR.

Heneveld, Craig. (1996). Schools Count: World Bank Project Designs and the Quality of Primar Education in Sub-Saharan Africa. Washington, DC: The World Bank.

Hill, N. E., \& Tyson, D. F. (2009). Parental involvement in middle school: A meta-analytic assessment of the strategies that promote achievement. Developmental Psychology, 45(3), $740-763$.

Hopkins. (1996). Theory for school development. Cassel, london. 
Hopkins, D. (1996). The future of research on School effectiveness and school

McClelland, M. M., Morrison, F. J., \& Holmes, D. H. (2013). Children at-risk for early academic problems: The role of learning-related social skills. Early Childhood Research Quarterly, 15, 307-329.

Ohba, A. (2012). Does Free Education enable the Poor to Gain Access? CREATE Pathways to Access. . Brighton: : University of Sussex Centre for International Education.

Omea, D. O. (2017). Effect of Increased Enrollment on Learning Resources in Public Primary Schools in Masaba South Sub-County, Kisii County, Kenya. International Journal of Novel Research in Education and Learning 4(1), 47-81.

Sheafer, S. (1994). Participation for Educational Change, a Synthesis of Experience. paris.

Watson. (1998). school community relationship. journal of research in Education, 4.

(2010). US Strategic dialouge on Education sector Development in Gilgit Balistan.

Tondeur, N. (2013). Roles, Duties and Responsibilities of School Management Team: Training Manual for Secondary School Managers. Kigali:. 